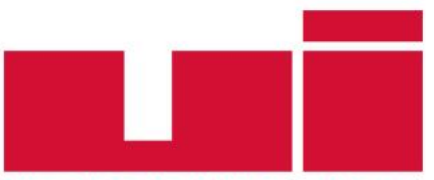

ULLUSLARARASIILIȘKiLER

Akademik Dergi

Yayın ilkeleri, izinler ve abonelik hakkında ayrıntılı bilgi:

E-mail: bilgi@uidergisi.com.tr

Web: www.uidergisi.com.tr

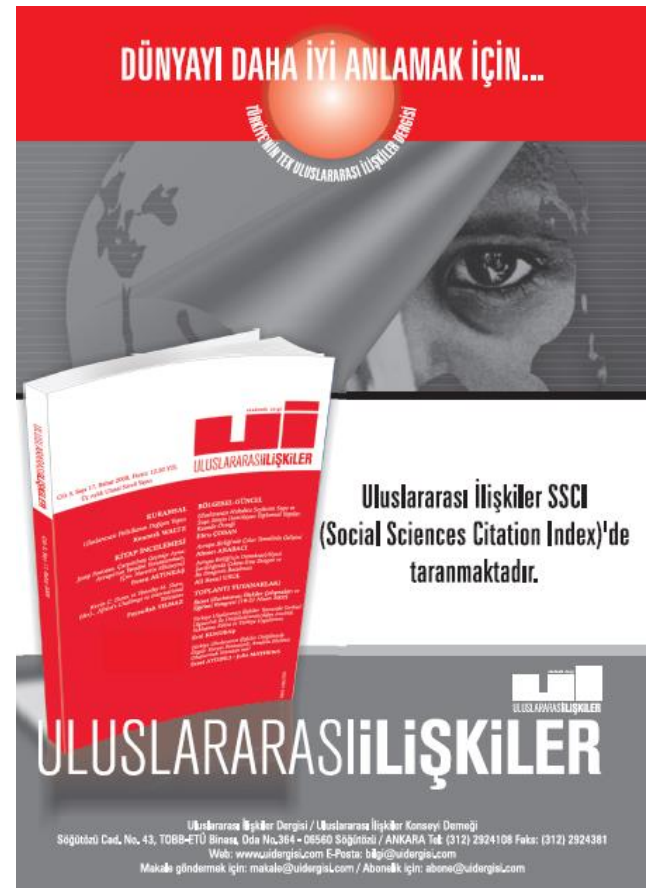

\title{
Azınlık Ícinde Azınlık Olmak (mı?): İsrail Vatandaşı Filistinli/Arap Kadınların İsrail Anaakım Basınında Temsili
}

\section{Umut KOLDAŞ*}

* Doç. Dr., Yakın Doğu Enstitüsü ve Uluslararası İlişkiler Bölümü, Yakın Doğu Üniversitesi

Bu makaleye atıf için: Koldaş, Umut, “Azınlık İcinde Azınlık Olmak (mı?): İsrail Vatandaşı Filistinli/Arap Kadınların İsrail Anaakım Basınında Temsili”, Uluslararası İlişkiler, Cilt 14, Sayı 56, 2017, s. 105-120.

Bu makalenin tüm hakları Uluslararası İlişkiler Konseyi Derneği'ne aittir. Önceden yazılı izin alınmadan hiç bir iletişim, kopyalama ya da yayın sistemi kullanılarak yeniden yayımlanamaz, çoğaltılamaz, dağıtılamaz, satılamaz veya herhangi bir şekilde kamunun ücretli/ücretsiz kullanımına sunulamaz. Akademik ve haber amaçlı kısa alıntılar bu kuralın dışındadır.

Aksi belirtilmediği sürece Uluslararası Illişkiler'de yayınlanan yazılarda belirtilen fikirler yalnızca yazarına/yazarlarına aittir. UİK Derneğini, editörleri ve diğer yazarları bağlamaz. 


\title{
Azınlık İçinde Azınlık Olmak (mı?): İsrail Vatandaşı Filistinli/Arap Kadınların İsrail Anaakım Basınında Temsili
}

\author{
Umut KOLDAŞ \\ Doç. Dr., Yakın Doğu Enstitüsü ve Uluslararası İlişkiler Bölümü, İIBF, Yakın Doğu Üniversitesi, KKTC. \\ E-posta:umut.koldas@neu.edu.tr
}

\begin{abstract}
ÖZET
Bu makalede İsrail vatandaşı Filistinli/Arap kadınların etnik, cinsiyetçi ve etno-cinsiyetçi hegemonyalarla ilişkileri bağlamında İsrail başat sistemi tarafından "bizdenleştirilmesi" ve "kontrollü olarak ötekileştirilmeleri" süreçlerinde İsrail anaakım basınının araçsallı̆ğ irdelenmektedir. Makalenin temel savı İsrail anaakım basınının İsrailliliksöylemine koşut bir şekilde İsrailliliği ve bütünleşmeyi ön plana çıkaran kadını kucaklayıp İsrailliliğin hâkim tanımına muhalif olan kadını ise kontrollü bir şekilde ötekileştirirken sistemsel eşitsizliğin cinsiyet boyutunu da önemsizleştirdiğidir. $\mathrm{Bu}$ savlara ulaşılırken İsrail'in en fazla tiraja sahip, uluslararası (diaspora) erişilirliği olan ve sanal ağ ortamında da bulunan 5 gazetesinde yayımlanmış metinlerin eleştirel söylem analizinden yararlanılmıstır. Metinler eleştirel medya kuramları perspektifinden ideolojik arkaplanlarının oluşumundaki dinamikler göz önünde bulundurularak değerlendirilirken, İsrail'de kadının tarihsel ve sosyolojik konumu, İsrail medyasında Filistinli/Arap vatandaşlarının temsiliyetinin tarihsel gelişimi, İsrail medyasında kadının temsili hakkındaki çalışmalara da atıfta bulunulmuştur. Makale eleştirel medya yaklaşımlarının anaakım medyanın cinsiyetçi, etnik veya etno-cinsiyetçi egemen ideolojileri yaygın kılma ve pekiştirmedeki araçsallığıyla ilgili savlarını doğrulamaktadır.
\end{abstract}

Anahtar Kelimeler: İsrail, Anaakım Basın, Filistinli/Arap kadın vatandaşlar, hegemonya, temsil, ataerkillik

\section{Minority within a Minority?: Representation of Palestinian Arab Female Citizens in Israeli Mainstream Press}

\begin{abstract}
This article examines instrumental role of Israeli mainstream press in the processes of "coalescing" and "controlled otherization" in line with the ethnic, gendered and ethno-gendered hegemonies. The article indicates that Israeli mainstream press generally undermines the gendered inequalities in Israel, while coalescing the Israel's Palestinian/ Arab female citizens who embrace their Israeliness, and otherizing the ones, who structurally criticize the dominant Israeli structure. Research underlying this article's analysis is supported by critical discourse analysis of news articles and editorials in Israel's five mostly circulated and internationally accessible Israeli newspapers, which also have online versions. The texts have been examined by referring to their ideological backgrounds through the theoretical lenses of critical media approaches. In order to better contextualize the ideological links of the texts with the Israeli dominant discourse, the article also refers to studies on the general status of women in Israel, historical evolution of status of Palestinian/Arab female citizens of Israel, representation of women and Palestinian/Arab citizens of Israel in Israeli media. On theoretical grounds, the article confirms the main arguments of critical media studies on the instrumental role of mainstream media in dissemination of dominant ideologies on ethnic, gendered and ethno-gendered grounds.
\end{abstract}

Keywords: Israel, Mainstream Press, Female Palestinian/Arab Citizens, Representation, Hegemony, Patriarchy. 


\section{Giriş}

İsrail vatandaşı Filistinli/Arap kadınların İsrail toplumunun farklı arayüzlerinde farklı kesimlerle yapmakta oldukları mücadele ve uzlaşılar, Filistinli/Arap kadının İsrail medyasındaki temsiline de yansımaktadır. İsrail medyası, Filistinli/Arap kadınların İsrail kamusal alanındaki mücadelesine zaman zaman belli bir duygudaşlıkla yaklaşsa da, çoğunlukla bu mücadeleyi başat İsrail değerler sistemi üzerinden değerlendirmekte ve İsrail'in yapısal bütünlügünü tehdit eder nitelik aldıklarında İsrail egemen sınıflarının ana söylemleri doğrultusunda kontrollü bir şekilde ötekileştirmektedir. Tarihsel olarak etno-cinsiyetçi bir egemen devlet söyleminin ideolojik bir aygitı şeklinde hizmet veren İsrail medyasında, Filistinli/Arap kadınların temsilinde izlenen söylemsel çizgi, toplumsal yapıdaki dönüşümlere koşut olarak güvenlik odaklı dizgesel bir ayrımcılıktan, rıza oluşturmaya dayalı bir başatlığa doğru evrilmiştir. Bu evrilme süreci İsrail ana-akım basınında İsraillilik değerler sistemine ve yapılarına İsrail vatandaşı Filistinli/Arap kadınların “bizdenleştirilmesi” ve bu sistem ve yapılara karşıt olanların ise "kontrollü olarak ötekileştirilmeleri” bağlamında hâkim bir söylemin gelişmesine neden olmuştur.

$\mathrm{Bu}$ arkaplan çerçevesinde bu makale, İsrail vatandaşı Filistinli/Arap kadınların İsrail anaakım basınındaki temsilini, İsrail devleti ve hakim söylemleriyle ilişkilerinde "eşitlik için bütünleşme" ve "eşitlik için direniş" yaklaşımlarının simge isimleri haline gelmiş Nof Atamna-İsmail ve Hanin Zoabi'nin 20142016 yılları arasında gazete haber ve yazılarındaki temsillerine atıfla tartışmaktadır. Atamna-İsmail'in İsrail Kanal-2 televizyonunda izlenme rekoruna ulaşan Master-Chef (Usta-Aşçı) isimli yemek yarışmasını kazandığı ve Hanin Zoabi’nin zorla kaçırılarak öldürülmüş üç Yahudi gençle ilgili yaptığı İsrail sistemini ve işgalini eleştiren yorumların İsrail basınında ve kamuoyunda tepki yaratmaya başladığı 2014 yılından 2016 yılının sonuna kadar çıkmış olan haberler ve editör yazıları eleştirel söylem analizi yöntemiyle bu dönemin koşulları ve arkaplanı göz önünde bulundurularak incelenmiştir.

Bu bağlamda, makalede öncelikle başat söylemin içine geliştiği ideolojik arkaplanı oluşturan yapı, etmen, süreç ve dinamikler tartışıldıktan sonra, İsrail anaakım basınında Atamna-İsmail ve Zoabi hakkında yayınlanmış haberlerin eleştirel söylem analizine dayanarak İsrail vatandaşı Filistinli/ Arap kadınların "bizdenleştirilmesi” ve kontrollü olarak ötekileştirilmeleri” sürecinde İsrail basınının söylemleri irdelenmiştir. Bu çerçevede, İsrail basınının en fazla baskı sayısına sahip ve uluslararası alanda Yahudi diasporasının da erişilirliği olan 5 gazetesinde (Hayom, Maariv, Yediot-Aharanot, Jerusalem Post ve Haaretz) 2014-2016 yılları arasında Nof Atamna-İsmail ve Hanin Zoabi hakkında yer almış haberlerle gazete yazıları eleştirel söylem analizine tabi tutulmuş ve ana-akım medya söylemini oluşturan koşullar dikkate alınarak değerlendirilmiştir.

Anaakım İsrail basınının popülist, ulusalcı, eleştirel ve diasporaya dönük niteliklerini temsil eden bu gazetelerin ${ }^{1}$ İbranice ve İngilizce sürümleri üzerinden yapılan eleştirel söylem analizinde,

1 İsrail medya uzamında Hayom gazetesi yaygın-popülist çizgiyi temsil ederken; Yedioth-Aharanot anaakım, güvenlik konularında muhafazakâr, medeni konularda daha liberal ve orta sınıfa hitap eden bir editoryal duruşu; Maariv anaakım, ulusalcı ve orta-üst demografik kesime hitap eden bir editoryal çizgiyi; Haaretz daha seçkinci eleştirel ortanın soluna yakın bir duruşu ve Jerusalem Post ise İngilizce bilen İsraillilere, İsrail'i anlamak isteyen yabancılara ve Yahudi diasporasına dönük anaakım bir çizgiyi temsil etmektedir. Gazetelerin İngilizce sürümleri ve Jerusalem Post okuyucu kitlesi olarak İsrail'i ve İbraniceyi bilmeyen yabancılara değil, anadili İbranice olmayan ancak İsrail'le duygu ve gelecek bağı olan Yahudi diasporasındaki okuyucu kitlesine de seslenmektedir. Bu nedenle İbranice ve İngilizce dile getirilişlerde dillerin özelliklerinden ve mesaj önceliklerinden kaynaklanan bazı farklılıklar olsa da bu farklılıklar bu gazetelerin genel editöryal politikalarında ve ana ideolojik duruşlarında yapısal bir farklılığa işaret etmemektedirler. İsrail basınının daha geniş analizi için bkz. Eytan Gilboa, “The Evolution of Israeli Media”, Middle East Review of International Affairs, Cilt 12, No.3, 2008, s.88-101; Dan Caspi ve Yehiel Limor, The In/Outsiders: The Media in Israel, New Jersey, Hampton Press, 1999. 
söylemin okuyucu üzerinde yaratacağı etkiden ziyade basın kuruluşlarının bu iki kadının medyadaki temsilinde kullandıkları söylemin hâkim ideoloji ve söylemle ne kadar örtüşük olduğu irdelenmiştir. $\mathrm{Bu}$ nedenle medya etki ve medya yetiştirme teorilerine değinilmemiş, bu kuramlar çerçevesinde kullanılan medya-izleyici-etkisi analiz yöntemleri tercih edilmemiştir. Bunun yerine makalenin araştırma sorusuyla bağdaşık olarak başat söylemin içine oluştuğu ideolojik çerçeveye ve söylemin ideolojik karakterine vurgu yapan eleştirel söylem analizi üzerinden İsrail basınında hâkim olan söylemin ataerkil İsraillilik hegemonyal söylemiyle bağdaşıllı̆̆ bağlamında "biz”, öteki” ve "öteki-biz" ayrımlarının yaratılmasındaki ideolojik araçsallığı sorgulanmıştır.

Değerlendirmenin kuramsal çerçevesi oluşturulurken başat toplumsal söylemi ve devlet söylemiyle medya ilişkisini inceleyen medya kuramlarından yararlanılmış ve hegemonyal ideoloji ve medya söylemi arasındaki ilişkinin niteliği irdelenmiştir. Bu konudaki kuramsal çalışmalarda medya genelde hegemonyal ideolojinin toplum tarafından içselleştirilmesini sağlayan bir araç ya da egemen ideolojiye alternatif (veya karşıt) düşünceleri ortaya koyan bir söylem-üretimi-yapılanması olarak sunulmuştur. Bu bağlamda, kuramsal dizginin bir ucuna başat medyayı diğer ucuna ise devrimsel bir karşı koyuşu savunan radikal medyayı yerleştirmek mümkündür. ${ }^{2}$ Gramşici çizgiyi izleyen medya kuramcıları medyanın egemen ideolojinin içselleştirilmesi sürecindeki rolüne değinmişlerdir. $\mathrm{Bu}$ anlamda Gramşici bakış açısıyla konuya yaklaşıldığında medyayı egemen ideolojiyi yaygınlaştıran ve pekiştiren bir araç olarak değerlendirmek mümkündür. ${ }^{3}$ Toplumdaki egemen grup veya sınıfların hegemonyası kültürel ve ideolojik olarak medyanın da aralarında bulunduğu kurumlar üzerinden işler ve toplum tarafından bu kurumların yardımı ve öncülüğüyle içselleştirilir. Bu süreçte medya, egemen ideolojinin toplum tarafından içselleştirilebilmesi için gerekli kültürel altyapıyı destekler ve böylelikle üzerine uzlaşılmış baskın değerleri ve normları yaygınlaştırarak güçlendirir. ${ }^{4} \mathrm{Bu}$ bağlamda Curran medyanın egemen kültürün yapıtaşları olan öğeleri yinelediğini, pekiştirdiğini ve yaygınlaştırdığını ifade eder. ${ }^{5}$ Hâkim konumdaki odakların söylemlerine koşut bir şekilde işleyen ${ }^{6}$ kitle iletişim araçları, toplumda bireylere yalnızca bilgi ve haber ulaştırmakla yetinmeyerek bireylerin düşünyönelimlerini egemen sınıfların çıkar ve önceliklerine göre yönlendirme ve düzenlemede etkin bir rol oynamaktadırlar. ${ }^{7}$ Bu kuramsal meyanda medya hegemonyal sınıfların çıkarları doğrultusunda işleyen ve egemen kültür normlarının toplumun farklı kesimlerince kabul edilebilir hale gelmesine ve/veya içselleştirilmesine hizmet eden araçsal bir yapılanma olarak değerlendirilmiştir. ${ }^{8}$

Kuramsal çatısını başat ideolojiyle medya ilişkisini inceleyen medya çalışmalarına dayandıran bu makalede analiz yöntemi olarak söylemin ideolojik karakterine vurgu yapan eleştirel söylem analizi kullanılmıştır. Bu yöntem söylemin analizini yaparken söylemle güç ilişkileri, ideolojiler ve toplumsal kimlikler gibi diğer sosyal etmenler arasındaki ilişkileri irdeler . ${ }^{9}$ Bu makalede İsrail gazetelerinin haber ve başyazılarına uygulanan söylem analizi Van Dijk'ın ve Fairclough'un eleştirel söylem

2 John. D. H. Downing, Radical Media, London, SAGE publications, 2001.

3 Dominic Strinati, An Introduction to Theories of Popular Culture, London and New York, Routledge, 1995.

4 Stuart Hall, “The Rediscovery of 'Ideology': Return of the Repressed in Media Studies", Michael Gurevitch et al. (der.), Culture, Society and the Media, London, Methuen, 1982.

5 Ibid.

6 Theodor W. Adorno, The Culture Industry, Londra, Routledge, 1991; Max Hokheimer ve Thodor W. Adorno, "The Culture Industry: Enlightenment as Mass Deception", Dialectic of Enlightenment, California, Stanford University Press, 2002, s.94-137.

7 Charles Wright Mills, İktidar Seçkinleri, İstanbul, Bilgi, 1974.

8 James Curran et al., Mass Communication and Society, Londra, Arnold, 1977.

9 Norman Fairclough, "Critical Discourse Analysis", James Paul Gee ve Michael Handford (der.), Routledge Handbook of Discourse Analysis, Londra ve New York, Routledge, 2012, s.9. 
yöntemi modellerinde ortaya konulan temel ilkeler izlenerek gerçekleştirilmiştir. Bir başka deyişle bu çözümleme yapılırken söylem analizinin metin analiziyle sınırlı olmadığı, söylemi derinliğine irdeleyebilmek için metin yapılarıyla bu yapıların üretildiği toplumsal, kültürel, tarihsel ve bilişsel ortamlar arasındaki ilişkinin de anlaşılması gerektiği göz önünde bulundurulmuştur. ${ }^{10}$

$\mathrm{Bu}$ çerçevede İsrail vatandaşı Filistinli/Arap kadınların basındaki temsillerinde İsrail gazeteleri tarafından ortaya konan söylemlerdeki olası ideolojik vurgu veya seçimleriyle metin yapılarının oluşum süreçlerinin "gerçeği” oluşturma ${ }^{11}$ ve "biz" ve "öteki” yi yansıtmadaki ${ }^{12}$ yerine de atıflar yapılmıştır. Analize konu metin yapılarıyla bu yapıların üretildiği toplumsal, kültürel, tarihsel ve bilişsel ortamlar arasındaki ilişkinin anlaşılması için İsrail'deki Filistinli/Arap kadın vatandaşların yapı içindeki konumları; İsrail'in egemen norm yapılarıyla uzlaşı ve mücadele süreçleri; İsrail medyasında kadının ve Filistinli/Arap vatandaşların temsiliyetinin dönüşümü de bu süreçle bağdaşıklıkları bağlamında ele alınmışlardır.

\section{İsrail'de Filistinli/Arap Kadın Olmak}

Etno-cinsiyetçilikten bağımsız eşitlikçi bir sosyo-ekonomik dizgesel altyapının henüz pekişmediği İsrail'de bu ülkenin vatandaşlı̆̆ını taşıyan Filistinli/Arap kadınlar, son yıllardaki eğitim seviyelerindeki önemli artışa karşın ${ }^{13}$ İsrail toplumunun çevre unsuru olmaya devam etmişlerdir. Hatta artan eğitim seviyesine rağmen değişmeyen toplumsal statüleri nedeniyle eğitimli Filistinli/Arap kadınları, İsrail'deki hâkim kültür, cinsiyet, ırk ve ulus yapılarının arasında karmaşık dengelerle belirlenen tekinsiz ve kenar alanda kendi kimliklerini sürekli bir şekilde müzakere etmek ve baskın toplumsal tanımlamalara meydan okumak durumunda kalmışlardır. ${ }^{14}$

$\mathrm{Bu}$ anlamda, mevcut toplumsal yapı içinde İsrail vatandaşı Filistinli/Arap kadınlar bir yandan birbiriyle ciddi şekilde çatışan diğer yandan birbirinden belli ölçülerde beslenen iki hegemonyaya karşı mücadele etmek veya onlarla uzlaşmak durumundadırlar. Bu hegemonyalardan ilki İsrail devletinin ve egemen toplum katmanlarının hâkim söylemi doğrultusunda farklı ideolojik aygitlar (medya, ordu, okullar) tarafından yürütülen ve İsraillilik üst kimliğinin içselleştirilmesini hedefleyen bir ulusalcı modernizasyon projesine dayanır. Bu hegemonyada İsrail vatandaşı Filistinli/ Arap bir kadının "İsraillilik" değerler sistemini içelleştirmesi veya bu değerlerin başatlığına rıza göstermesi, İsrail sosyo-ekonomik yapısı içinde "eşit” olabilmesinin ön koşulu haline gelmektedir. İkinci hegemonya ise Filistinli/Arap erkekler tarafından Filistinli/Arap kadın üzerinde oluşturulan geleneksel değerler hegemonyasıdır. Kadının ikincil rolünü önemsemeyen, kabul eden veya pekiştiren bu hegemonya bir yandan İsraillilik temelli modernleşme projesine Filistinlilik temelinde bir karşıhegemonya geliştirirken diğer yandan geleneksel değerlere dayanarak kendi içindeki Filistinli/ Arap kadınlar üzerinde tahakküm kurabilmektedir. Bu çerçevede Filistinli/Arap kadınlar bir hegemonyaya karşı mücadele ederken diğer hegemonyanın etkin olmayan unsuruna veya madununa dönüştürülebilmektedirler. ${ }^{15}$

10 Teun Van Dijk, "Principles of Critical Discourse Analysis”, Discourse and Society, Cilt 4, No.2, 1993, s.249-283.

11 Norman Fairclough, Media Discourse, London, Arnold, 1995.

12 Lütfiye Oktar, "The Ideological Organization of Representational Processes in the Presentation of us and them", Discourse and Society, Cilt 12, No.3, 2001, s.313-346.

13 Suheir Abu Oksa Daoud, Palestinian Women and Politics in Israel, Florida, University Press of Florida, 2009, s.18.

14 Hanna Herzog, “'Both an Arab and a Woman': Gendered Racialised Experiences of Female Palestinian Citizens of Israel”, Social Identities, Cilt 10, No.1, 2004, s.53-82.

15 Janani Balasubramanian ve Alok Vaid-Menon, "A New Wave of Palestinian Youth Activism in Response to Israeli Prawer Plan”, 19 Ağustos 2013, http:// www.momken.org/?mod=articles\&ID=5693, (Erişim Tarihi 9 Ocak 2015). 
Filistinli/Arap kadınlar bu hegemonyalardaki ikilemleri aşabilmek adına Kandiyoti’nin "ataerkil pazarlıklar” şeklinde tanımladığı ${ }^{16}$ ve kadınların ataerkil toplumda güvenliklerini ve diğer ihtiyaçlarını karşılamak ve toplumsal konumlarını korumak/ilerletmek için uygulamaya koydukları müzakere stratejilerini ve ilişkiler ağını içeren uzlaşı süreçlerini hem Filistinli/Arap erkekler, hem de İsrailli erkek ve kadınlarla deneyimlemişlerdir. Ataerkil sistemin ve altsistemin başat unsurlarıly yapılan pazarlıklar sırasında cinsel kimlikler ve hiyerarşiler bazen birbirleriyle çatışarak, bazense uzlaşarak ve yeniden üretilerek hem siyasi anlamda araçsallaştırılmış hem de toplumsal kimlikler için önemli tutunum noktaları olmuşlardır. ${ }^{17}$

İki düzlemde gerçekleştirdikleri toplumsal kimlik mücadelelerinde cinsiyet temelli hiyerarşileri hesaba katmak zorunda kalan İsrail vatandaşı Filistinli/Arap kadınlar, bu süreçte zorluklarla karşılaşmaktadırlar. Bu zorlukların bir kısmı İsrail hukuk yapısına hâkim olan güvenlik odaklı siyasi düşünce sisteminin geleneksel olarak Filistinli/Arap vatandaşlara yönelik kontrol kaygısından ve politikalarından kaynaklanmaktadır. Kuruluşundan itibaren Filistinli/Arap vatandaşlarını İsrail devletinin siyasi bütünlüğüne karşı potansiyel bir tehdit unsuru olarak gören İsrail siyasi yapısı, sisteme muhalif yapılanmalara şüpheyle yaklaşmış ve bunların faaliyet alanlarını mümkün olduğunca daraltmaya veya kontrol altına almaya çalışıştır. ${ }^{18}$ Bu şartlar altında Filistinli/Arap kadınların toplumsal konumlanış mücadeleleri İsrail'in siyasi, ekonomik ve hukuksal kontrol mekanizmalarının belirlediği sınırlı hareket alanı içinde gerçekleşebilmiştir.

Zorlukların diğer kısmı, Filistin kadın eylemciliğinin bölünmüşlüğü nedeniyle ortaya çıkmaktadır. Filistinli/Arap kadınların azınlık içinde azınlık oldukları İsrail kamusal alanı çok çeşitli toplum kesimlerinden oluşmaktadır. Bu alan içinde, İsrail vatandaşı Filistinli/Arap kadınlar laik İsrail toplumunun, Yahudi dini grupların, İsrail kadın hareketlerinin, batılılaşma ve küreselleşmenin yerel uyarlamalarının ve İsrail içindeki Filistin toplumunun değişen iç dinamiklerinin belirlediği farklı norm yapılar $1{ }^{19}$ çerçevesinde toplumsal ilişkilerini düzenlerken farklı toplumsal arayüzlerde ya mücadele etmekte ya da başat yapılarla uzlaşmaktadırlar. İsrail-Filistin cinsiyet düzenini oluşturan rejimler ve unsurlar (aile, devlet, ulusal/etnik toplumsal hareketler) arasındaki yapısal gerilimleri göz ardı eden üst-düşünsel yaklaşım ${ }^{20}$ da Filistinli/Arap kadınların aralarındaki bölünmüşlügü pekiştirmekte ve onların cinsiyet temelli bütünlüklü bir karşı-hegemonya stratejisi geliştirmelerini zorlaştırmaktadır.

Bu süreçte İsrail medyası başat İsraillilik söylemi bağlamında İsrailliliği benimseyen Filistinli/ Arap kadınları "bizden” veya "bütünleşmiş" İsrailliler şeklinde yansıtırken, İsrailliliği eleştiren ve ona muhalif olan Filistinli/Arap kadın vatandaşların tabi tutulduğu kontrollü ötekileştirmeninse ideolojik bir aracı olarak işleyebilmektedir. Bu anlamda İsrail medyası, İsrail vatandaşı Filistinli/Arap kadınların bölünmüşlügünün İsrail medya uzamında ve dolaylı olarak medyanın etki ettiği kamusal alanda pekiştirilmesine de hizmet etmektedir.

16 Deniz Kandiyoti, “Bargaining Patriarchy”, Gender \& Society, Cilt 2, No.3, 1988, s.274-290.

17 Hanna Herzog ve Taghreed Yahia-Younis, "Men’s Bargaining with Patriarchy, The Case of Primaries within Hamulas in Palestinian Arab Communities in Israel”, Gender \& Society, Cilt 21, No.4, 2007, s.579-602.

18 Ian Lustick, Arabs in the Jewish State: Israel's Control of a National Minority, Austin ve Londra, University of Texas Press, 1980.

19 Khawla Abu Baker, "Career women” or "working women”? change versus stability for young Palestinian women in Israel”, Journal of Israeli History, Cilt 21, No.1-2, 2002, s.85

20 Amalia Sa'ar, "Contradictory Location: Assessing the Position of Palestinian Women Citizens of Israel”, Journal of Middle East Women's Studies, Cilt 3, No.3, 2007, s.45-74. 


\section{İsrail Medyası ve Filistinli/Arap Vatandaşların Temsili}

İsrail'de demokratik yapının inşası ve pekişmesi sürecinde medya, İsrail'in yönetici seçkinlerinin ihtiyaçlarıyla İsrail demokrasisinin normları arasında bir köprü oluşturmuş ve egemen siyasi yapılanmanın mesajlarını toplumun farklı kesimlerine anlayabilecekleri bir dil ve üslupla aktarabilmeleri için ideolojik bir zemin yaratmıştır. ${ }^{21}$ İsrail demokrasisinin kendine özgü özel koşulları çerçevesinde kendisine sosyal sorumluluk görevi yüklenen İsrail medyası, sözüm ona aydınlanmacı bir otoritenin ideolojik aygıtı olarak işlemeye devam ederken, kamusal hizmet merkezlilikten ekonomik kar merkezliliğe geçtiğinde medyanın ekonomi-politik yapısındaki dönüşüm onun ideolojik araçsallığında köklü bir değişim yaratmamıştır. ${ }^{22}$

Filistinli/Arap İsrail vatandaşları 2000’li yılların başına dek gerek medya profesyonelleri olarak gerekse medya konusu olarak İsrail medya alanının çevre unsuru olmuşlardır. El-Aksa İntifadası sonrası dönemde ana-akım medyanın söyleminde gelişmeye başlayan siyasi doğruculuk yaklaşımının da etkisiyle basındaki güvenlik odaklı açıkça ayrımcı ve ayrıştırıcı söylemlerin yerini zaman zaman Filistinli/Arap vatandaşlarla duygudaşlık kurma çabasını da içeren ${ }^{23}$ "kontrollü ötekileştirici” ve/veya "uzlaştırıcı" söylemler almaya başlamıştır. El-Aksa intifadasının en gerilimli anlarında bile Filistinli/ Arap vatandaşlarını yalnızca devlet sistemine karşı gelen şiddet yanlısı eylemciler olarak değil, aynı zamanda siyasi liderler, kurbanlar, görgü tanıkları olarak yansıtan ve insani yönlerini belirterek atıflayan $^{24}$ bu yeni temsil biçimleri, yeni dönemde İsrail medya söylemindeki değişimin işaretleri olarak yorumlanmıştır. ${ }^{25}$

Yeni dönemde İsrail medyasının Filistinli/Arap vatandaşlara yönelik başat söyleminde "sistem-içilik" ve "sisteme-karşıtllk" izgesinde belirlenen kontrollü ötekileştirmenin ön plana çıktı̆̆ görülmektedir. İsrail'in hâkim sistemiyle uzlaşının övüldügü ve Filistinli/Arap vatandaşlardan yöneltilebilecek sistem-içi eleştirilere göreli bir serbest alanın açıldığı baskın söylem doğrultusunda ana-akım İsrail medyası Filistinli/Arap vatandaşları temsilinde onları kategorik ve sistemli ötekileştiren ayrıştırıcı gizil (veya bariz) bir nefret söylemi kullanmamıştır. Bunun yerine görünürde daha siyaseten doğru, bütünleştirici ve kapsayıcı olan ama aynı zamanda sistem karşıtı Filistinli/Araplara yönelik kontrollü bir ötekileştirmeyi içeren medya söylemini kullanmaya başlamıştır.

\section{İsrail Medyasında Kadının Temsili}

1990’lı yılların sonuna kadar ataerkil egemen bir yapı ve içeriğe sahip olan İsrail medyasında kadın geleneksel olarak hem haber programları, gazeteler, sosyal programlar gibi gerçeklik odaklı medya ürünlerinde hem de diziler, filmler, çocuk programları gibi eğlence odaklı medya yapımlarında, istisnai, marjinal, eksik, zayıf bir "öteki” ve "azınlık" olarak sunulmuştur. ${ }^{26}$ Kadının erkeğe oranla

21 Dan Caspi, "On Media and Politics: Between Enlightened Authority and Social Responsibility", Israel Affairs, Cilt 11, No.1, 2005, s.23-38.

22 Ibid.

23 Ilan Asya, “The Israeli Newspapers' Coverage of the Israeli Arabs during the Second Intifada”, Alexander Bligh (der.), The Israeli Palestinians: An Arab Minority in the Jewish State, Portland, Frank Cass, 2003, s.204.

24 Tamar Liebes ve Kampf Zohar "Black and White and Shades of Gray: Palestinans in the Israeli Media during 2nd Intifada”, The International Journal of Press/Politics, Cilt 14, No.4, 2009, s.451.

25 Ibid., s.434-453

26 Dafna Lemish, "Exclusion and Marginality: Portrayals of Women in Israeli Media”, Karenn Ross ve Carolyn M. Byerly (der.), Women and Media International Perspectives, Malden, Blackwell, 2004, s.39-60. 
medya ortamlarında niceliksel olarak yetersiz, niteliksel olarak ise yanlı ve peşin hükümlü temsili, 2000'li yılların başına kadar ataerkil egemen İsrail medyasının belirgin özelliklerinden biri olmuştur. Bu dönemde İsrail medyası kadını yaygın ataerkil önyargılar ve basmakalıp genellemelerle tanımlamış ve genellikle ikincil rollerde ve bir haber öyküsünün mağduru, kurbanı, çaresiz veya etkisiz öğesi olarak yansıtmıştır. ${ }^{27}$

İsrail medyası siyaset alanındaki farklı konuları işleyişinde ve temsilinde de kadına siyasi erkini ve yetkinliğini yansıtması bağlamında daha az yer ayırmış, kadını ataerkil yapının ona biçtiği geleneksel "çocuk yetiştiren ana ve bakıcı" rollerinde sunmayı tercih etmiştir. ${ }^{28}$ Bu programlarda kadınlar liderler olarak değil, erkek liderlerin arkasında onlara destek olan, ikincil ve bağımlı statüleri toplumca da kanıksanmış (hatta takdir edilen) bireyler olarak yansıtılmışlardır. ${ }^{29}$ Bu bağlamda kadının temsili de 1990’lı yılların sonuna dek erkek/kamusal/siyasi olanla dişi/özel/siyaset dışı veya apolitik olan arasındaki ikiliğin belirlediği ve temel olarak kadını kamusal alandan ve siyasetten dışlayan toplumsal çerçeveler içinde gerçekleşmiştir. ${ }^{30}$

2000’li yılların başında kadınların toplum yapılanması içindeki konumlanışında yaşanan dönüşümü ve medya endüstrisinde kadın sayısının artması, kadının medyadaki temsilinde de değişimlere yol açmıştır. Bu dönemde kadın, iş hayatının etkili bir parçası olarak resmedilmeye başlanmış, geleneksel anne ve bakıcı rollerinin dışına çıkarak etkin politikacılar, iş insanları, düşün insanları olarak medyada daha görünür hale gelmiştir. Ancak bu durum beraberinde ataerkil sistemde cinsiyet eşitliği yönünde bir yapı-bozumunu veya yapısal bir dönüşümü getirmemiştir. Kadın ve erkeğin medya temsilinde gerçekleşen bu sistemiçi değişim İsrail medyasında kendine özgü bir kadın bakış açısının, kadın dünya görüşünün veya kadın odaklı değerler sisteminin özgürce dışavurumunu sağlayacak yapısal bir devrime önayak olmamıştır. ${ }^{31}$

İsrail medyası İsrail'deki cinsiyetçi sistemin sürekli kılınmasına cinsiyet-içi bölünmüşlüğü medya alanında pekiştirerek de yardımcı olmuştur. Etno-kültürel hâkim ideoloji doğrultusunda İsrail'deki kadınları etnik kökenlerindeki farklılıklarına koşut bir şekilde temsil eden İsrail medyası, Yahudi-Arap/Filistinli kadınların olduğu kadar Batılı (Aşkenaz) Yahudi kadınlarla Ortadoğu ve Afrika kökenli (Mizrahim, Etiyopyalı vb.) Yahudi kadınları arasındaki bölünmüşlüğü de belli başlı önyargıları ve atıf noktalarını kullanarak beslemiştir. İsrail medyası İsrail vatandaşı Filistinli/Arap kadınlarının temsilinde bu bölünmüşlügün İsrail ulusal kimliğini yadsımayanlar ve buna karşı olanlar çatkısında üretilmesine ve yaygınlaşmasına hizmet etmiştir. ${ }^{32}$

27 Mira Ariel, "Female and Male Stereotypes in Israeli Literature and Media: Evidence from Introductory Patterns", Language and Communication, Cilt 8, No.3, 1988, s.43-68.

28 Dafna Lemish ve Chava E. Tidhar, "The Silenced Majority: Women in Israel's 1998 television election campaign." Women and Language, Cilt 14, No.1, 1991, s.13-21; Lemish ve Tidhar, "Still Marginal: Women in Israel's 1996 television election campaign., Sex Roles, Cilt 41, No.5, 1999, s.389-412.

29 Dafna Lemish ve Inbal Barzel, "Four Mothers:' The Womb in the Public Sphere”, European Journal of Communication, Cilt 15, No.2, 2000, s.147-169.

30 Hanna Herzog, "More than a Looking Glass Women in Israeli Local Politics and the Media", The International Journal of Press/Politics, Cilt 3, No.1, 1998, s.26-47.

31 Lemish, "Exclusion and Marginality", 2004, s.39-60.

32 Amit-Lavie-Dinur, Yuval Karnier ve Tal Azran, “'Bad Girls': the use of gendered media frames in the Israeli media's coverage of female political criminals”, Journal of Gender Studies, Cilt 24, No.3, s.326-346. 


\section{İsrail Medyasında Filistinli/Arap Kadının "Bizden" ve "Öteki" Şeklinde Temsili}

Filistinli/Arap kadınların medyadaki temsili de İsrail medyasının yapı, alışkanlık ve uygulamalarından bağışık olmamıştır. İsrail medyası 1990'ların başına dek uzun yıllar Filistinli/Arap kadınları ya yok saymış ya da görmezden gelmiştir. İlerleyen dönemlerde İsrail vatandaşı Filistinli/Arap kadınlar İsrail medyası tarafından önce İsrail açısından iç tehdit unsuru sayılan bir toplumsal alt kesimin bireyleri olarak tasvir edilmişler, zaman içinde ise yeni bir İsraillilik başatlığında rızası alınarak İsraillileştirilmeye çalışılan, buna direnenlerinse ötekileştirildiği bir kitleye dönüşmüşlerdir. Bu anlamda İsrail anaakım medyası söylemsel düzlemde Filistinli/Arap kadınların kategorilere ayrılarak bölünmesine ve böylelikle ortak bir zeminde baskın söyleme karşı bütünlüklü bir karşı duruş geliştirmelerinin zorlaşmasına hizmet etmektedir.

İsrail vatandaşı Filistinli/Arap kadınların medya temsiliyle ilgili yakın tarihli iki çarpıcı örnek İsrail medyasının bu temsildeki önceliklerini ve sınırlarını göstermektedir. Hanin Zoabi, İsrail parlamentosu Knesset te Balad Partisi'nin milletvekili olarak görev yapan bir kadın siyasetçidir. İsrail'in siyasi erk mücadelesinin merkezinde bulunan İsrail Parlamentosu’na bir Filistinli/Arap olarak girmeyi başaran Zoabi, İsrail medyasında İsrail siyasi sistemine ve egemen ideolojisine yönelttiği keskin eleştirilerle yer almıştır. Evlenip boşanmış olan Zoabi, medeni durumu itibariyle İsrail toplumunun Filistinli/Arap ataerkil kesimlerinin başat değerleriyle birebir örtüşmeyen ve geleneksel olarak pek tasvip edilmeyen bu medeni durumuna rağmen partisinden seçimlere ön sıralarda girip milletvekili seçilerek bu kesimin ataerkil yapısının sınırlarını da aşmıştır.

İsrail vatandaşı Filistinli/Arap kadınların İsrail medyasında "bizdenleştirici" söylemle temsiline en iyi örneklerden biri ise Nof Atamna-İsmail'in anaakım basındaki temsilidir. 2014 yılında İsrail'in Kanal-2 Televizyonu'nda yayınlanan Master-Chef isimli aşçlık yarışmasını kazanan Atamnaİsmail'in başarısı anaakım basın tarafından İsraillilik ortak zemininde toplumsal bütünleşmenin ve birlikte yaşama kültürünün başarılı bir örneği olarak sunulmuştur. Yarışmaya İsrail'de Filistinli/ Arap vatandaşların yoğun olarak yaşadığı yerleşim bölgelerinden biri olan Baka-el-Garbiye şehrinden katılan Atamna-İsmail, Master-Chef yemek yarışmasında birinci olduğunda, hem Yahudi hem de Filistinli/Arap izleyicilere, İsrail'in başat değerler sistemi içinde o sistemi içselleştirerek veya ona rıza göstererek uzlaşının mümkün olduğu mesajını basit ve anlaşılır bir şekilde vermiştir. Atamna-İsmail, mikrobiyoloji doktorasına sahip, Arapça, İbranice ve İngilizce bilen aynı zamanda çocuklarına ailesine karşı sorumluluk ve görevlerini yerine getiren bir İsrail vatandaşı Filistinli/Arap kadındır. Bu iki kadının birbiriyle geçişmiş ataerkil Yahudi merkezli İsraillilik ve ataerkil Filistinlilik hegemonyalarıyla ilişkilerindeki farklılıklar onların İsrail gazetelerindeki temsiline de yansımıştır

\section{Hanin Zoabi: Devlet Düşmanı Kışkırtıcı mı yoksa Siyasi Linç Mağduru bir Günah Keçisi mi?}

Anaakım İsrail gazeteleri, söylem bazında, İsrail devlet politikalarını ve Filistinli/Arap İsrail vatandaşlarını dışlayan ideolojik simgelerini eleştiren Zoabi’nin sisteme yapısal bir tehdit olarak algılanabilecek söylemleri karşısında farklılaşan ancak ötekileştirme pratiği açısından benzeşen bir karşı-söylem çizgisi izlemişlerdir. Tüm sistem dışı veya karşıtı görünen yaklaşımlarına rağmen Zoabi’ye bir karartma getirip onu mutlak bir şekilde dışlamamıs, zaman zaman ağır tonlarda eleştirerek ve siyasi suçlu şeklinde sunarak ${ }^{33}$ da olsa kendisini ve söylemlerini kontrollü bir şekilde ötekileştirerek temsil

33 Lavie-Dinur, "Karnier ve Azran” s.339-340. 
etmişlerdir. Hayom, Maariv, Yediot-Aharonot, Jerusalem Post gazetelerinde yer alan haber veya gazete yazılarında, başat söyleme karşıt olarak görülen Zoabi'yi ötekileştirirken, Zoabi’nin kadınlığından çok sisteme oluşturduğu tehdide vurgu yaptıkları görülmektedir. Bu yaklaşım, İsrail medyasının ilk dönemlerindeki açık etno-cinsiyetçi duruşundan bir farklılığa işaret etmektedir. Bir başka deyişle, Zoabi’nin İsrail anaakım basınında kontrollü ötekileştirmesi bariz cinsiyetçi bir ayrıştırma üzerinden değil, İsraillilik başat değerlerine karşı koyuşu üzerinden yapılırken, Zoabi'nin cinsel kimliği gazete yazılarında ana ötekileştirmeyi besleyen bir yan ötekileştirme pratiği olarak yer almıştır.

Hayom Gazetesi, Hanin Zoabi’nin İsrail'in başat değerleri karşıtı duruşunu popülist bir dille eleştirirken, Zoabi'nin İsrail toplumunun bir parçası olmadığının ve hem Yahudi hem de Filistinli/Arap İsrail vatandaşları tarafından dışlanması gereği üzerinde durmuştur. Zoabi’yi İsraillilik değerlerine varoluşsal tehdit oluşturan anti-semitik ve şiddet yanlısı bir düşman olarak resmeden Hayom, hainliğin ancak İsrail toplumunun bir parçası olma durumunda söz konusu olabileceği mesajını da aktarmıştır ${ }^{34}$. Zoabi’nin hiçbir zaman İsrail'i tehdit eden unsurlara sırtını dönmediğini vurgulayan yazıda, Zoabi’nin İsrail'de yaşayan Yahudilerle Araplar arasındaki ilişkiye ve temsil ettiği Arap toplumuna zarar verdiği ifade edilmektedir. Zoabi’nin cezasının Yahudiler tarafından değil, kendi topluluğu ve Arap seçmeni tarafından Zoabi'yi dışlayarak verilmesi lazım geldiği de belirtilen yazıda, böylesi bir ötekileştirmeyi desteklemek için İsrail başat yapılarının Filistinli/Arap vatandaşları sistem-içileştirmek adına daha etkin adımlar atmaları (Arapların akademideki varlıklarını arttırmak, kalabalık bölgelerde daha rahat yaşama imkânı sağlamaya yönelik verilen imar izinlerini kolaylaştırmak vb.) gerektiği ifade edilmiştir. ${ }^{35}$ Zoabi'yi dikkati üzerine çekmek için sürekli provokasyonlar yaratan köyün delisine benzeten diğer bir yazıda Zoabi, tarih boyunca Yahudilerin yok edilmesiyle bağlantılı görülen tarihsel kişiliklerle benzetilmiş ve Yahudilerin yanı sıra farklı dinlere mensup kişilere şiddet gösteren ve hatta Filistinli Fetih örgütünün üst düzey yetkililerini bile öldürmekten çekinmeyen Müslüman erkek kardeşlerinin gerçekleştirdiği şiddet eylemlerine karşı durmadığı ve Yahudilerin öldürülmesine tepki vermediği için eleştirilmiştir. ${ }^{36}$ Hayom'un bir başka temsilinde Zoabi, Nazi Almanya'sının propaganda bakanı Goebels'le benzeştirilerek ötekileştirilmiş, kendisinin ifade özgürlüğünü ve bireysel haklarını güvence altına alan İsrail demokrasisiyle alay eden, İsrail ordusunu kışkırtmakta İslamcı teröristlerle birlik olan, İsrail içindeki Arap ve Yahudiler arasındaki yabancılaşmayı ve kutuplaşmayı arttıran ve İsrail devletine bağlllık yemini etmesine rağmen bu yemini her fırsatta bozan bir kişi şeklinde resmedilmiştir. ${ }^{37}$ Hayom, Zoabi’ye İsrail başat değerlerine karşıt duruşunu devam ettirecekse bu yapının içinde olmaması gerektiği mesajını vermiş, bu değerleri temsil eden sistemin kendisine verdiği hak ve özgürlükleri o sisteme zarar vermek için kullanmaması konusunda uyarmıştır. Hayom'un Zoabi'yi ötekileştirmesinde Zoabi’nin söylemlerine karartma getirilmemiş, kontrollü ötekileştirme Zoabi'nin söylemlerinin çerçeve dışılaştırılması ve başat söylemin doğruları bağlamında yeni bir çerçevede eleştirilmesi üzerinden gerçekleştirilmiştir.

Maariv'in Zoabi'yi temsilinde en dikkat çeken noktalardan biri, Zoabi'ye modern, bekâr/ boşanmış, bakımlı bir Arap kadını olarak içinde yaşadığı demokratik değerlere saygılı, modern ülkedeki özgürlüğün değerini bilmesi gerektiğine dair yapılan eleştirel hatırlatmadır. Bu bağlamda Zoabi’ye

34 Dan Margalit, “Zoabi bir Hain Değil, O bir Düşman”, [Zoabi Lo Bogedet, Hi Haoyev], Israel-Hayom, 30 Haziran 2016, http://www.israelhayom.co.il/opinion/393349 (Erişim Tarihi 31 Mayıs 2107).

35 Ibid.

36 Reuven Barko, “Zoabi’nin Bağlantıları” [Hasotziatziot şel Zoabi], Israel-Hayom, 10 Kasım 2015, http://www. israelhayom.co.il/opinion/328319 (Erişim Tarihi 31 Mayıs 2017).

37 “MK Zoabi İsrail demokrasisiyle alay ediyor" [HK-Havera Knesset-Zoabi loagat Ledemokratia HaIsraelit], Israel-Hayom, 30 Haziran 2016, http://www.israelhayom.co.il/article/393359”, (Erişim Tarihi 30 Mayıs 2017). 
Suriye'de doğmuş olsaydı İsrail'e karşı gösterilere katılmak yerine evinde kendisinden yaşlı kocasından doğurduğu bebeğini emzirmekle meşgul olacağı; 47 yaşında bekâr bir kadın olarak makyajını yapabilen ve yüzü açık bir kadın olmak yerine çarşafla kapanacağı; Gazze’ye giden Türk gemisinde seyahat etmek, kariyerinde ilerlemek, yaşamını kazanmak ve medyada görünür olmak yerine kocasının aileye (kuma olarak) yeni katılan genç ikinci karısıyla rekabet ve mücadele edeceği hatırlatılmıştır. ${ }^{38}$ İsrail’ in varoluşsal temellerini eleştiren Zoabi'nin bu eleştiriyi yapabilmesinin bile o eleştirdiği ülkenin bir vatandaşı olması sayesinde mümkün olabildiği vurgulayan Maariv'de şu noktalar belirtilmektedir:

[B] ugün Zoabi pantolon giyebiliyorsa, kadınların, eşcinsellerin ve transseksüellerin hakları için mücadele verebiliyorsa ve ifade özgürlügünün himayesinde en aşırı ve yıkıcı pozisyonlar alabiliyorsa, bu Yahudilerin yıllar önce Uganda'yı kendilerine vatan olarak kabul etmemeleri, atalarının topraklarında bataklıkları kurutarak üniversiteler inşa etmeleri ve muhteşem bir Batı ülkesi kurmaları sayesindedir. ${ }^{39}$

Maariv, İsrail toplumunda Araplara ve kadınların Arap toplumları içindeki yerine ilişkin yaygın önyargıları anıştırarak, Zoabi’yi İsrailli bir kadın olmanın özgürlügünü yaşarken kendisine bu özgür ortamı yaratan İsrailliliği yıkmaya çalışma hayali kurduğu için eleştirmiş ve ötekileştirmiştir.

Yediot-Aharanot, Zoabi'yi temsilinde Zoabi'nin İsrail devletine ve söylemlerine karşı faaliyetlerini ve özellikle de İsrail devletini Nazi Almanya'sına benzetmesi ${ }^{40}$ ve İsrailli üç Yahudi genci kaçıran Filistinlileri terörist olarak görmediğini açıklaması ${ }^{41}$ gibi eylem ve söylemlerini ön plana çıarmıştır. İsraillilik değerlerine inanmış bir okuyucu kitlesi için rahatsız edici olabilecek bu haberlerde Yediot-Aharanot, Zoabi'ye karşıt fikirde olan ve Zoabi’nin İsraillilik değerlerine karşı tutumunu eleştiren meclis üyelerine ya da siyasi figürlere de yer vererek Zoabi'nin söylemlerini dengeleyerek veya ikincil kılarak ötekileştirmiştir. Haber metinlerinin satır aralarında Zoabi’nin başat yapı karşıtı önceki eylem ve söylemlerine yer veren Yediot-Aharanot, Zoabi'yi okurlarına tanıtırken polemik yaratan, provokatif, bir çok kişi tarafından İsrail karşıtı olarak tanımlanan eylemleriyle tanınan, geçmişte faaliyetleri ve söylemleri nedeniyle başı yasalarla derde girmiş, hakkında 2010 Gazze filosuna katılımı nedeniyle dokunulmazlığını kötüye kullanmaktan soruşturma açılmış bir Arap milletvekili olarak anımsatmıştır. ${ }^{42}$ Yediot-Aharanot'un görüş, karşı-görüş ve köşe yazılarında Zoabi, İsrail'in bir arada yaşam kültürünü tehdit eden bir saatli bombaya benzetilirken, toplumun faydasına bir kanunun bile çıkarılmasına katkı koymayan, İsrailli Arap toplumunu temsil etmeyen ve İsrail'deki Yahudi ve Arapların birlikte yaşayabilme olasılığını tehlikeye atan kışkırtma bağımlısı bir tehdit olarak nitelenmiştir. ${ }^{43}$ Zoabi ve onun gibi düşünenlerin ortaya çıkmasında İsrail'deki Arap toplumuyla İsrail devleti arasındaki ilişkilerin tam anlamıyla kurumsallaştırılamamış olmasının ve Arap vatandaşların

38 Michael Kleiner, "Hanin'in Hayalleri: Hayatı bir Arap Ülkesinde Neye Benzerdi?” [Hahalomot şel Hanin: Eh Hiu Nrim Hiye Bemedina Aravit?] ", Maariv, 17 Temmuz 2016, http://www.maariv.co.il/journalists/Article-549639, (Erişim Tarihi 30 Mayıs 2017).

39 Ibid.

40 “Tahrik konuşması: Zoabi Hollanda'da Kristallnacht Anma Töreninde” [Nu'm Hasatah: Zoabi Betekes Laila Bdlahat Beholand], Yediot-Aharanot, 9 Kasım 2015, http://www.ynet.co.il/articles/0,7340,L-4722737,00.html (Erişim Tarihi 31 Mayıs 2017).

41 "Kidnappers are not terrorists", Yediot-Aharanot, 17 Haziran 2014,http://www.ynetnews.com/articles/0,7340, L-4531428,00.html (Erişim Tarihi 31 Mayıs 2017); “Zoabi: Güvenlik istemiyorum, adam kaçıranlar (bunu) çaresizlikten yaptılar" [Zoabi: Lo Rotza Avtahah Hahotefim Palu Miyeuş], Yediot-Aharanot, 18 Haziran 2014, http://www.ynet.co.il/ articles/0,7340,L-4531911,00.html (Erişim Tarihi 31 Mayıs 2017).

42 Ibid.

43 Yoaz Hendel, "A red flag before another political murder”, New York Times, 13 Kasım 2015, http:/ /www.ynetnews.com/ articles/0,7340,L-4725071,00.html, (Erişim Tarihi 31 Mayıs 2017). 
kendilerini İsrail devletiyle özdeşik tanımlamalarına olanak verecek yasal mekanizmaların işlerlik kazanmamasının büyük payı olduğuna vurgu yapılan yazılarda Zoabi, İsrail'deki ortak yaşama tehdit oluşturması nedeniyle kontrollü bir şekilde ötekileştirilmiştir.

İbranice bilmeyen yeni göçmenler ve diaspora Yahudileri arasında önemli bir okuyucu kitlesine sahip olan Jerusalem Post, Zoabi'yi temsilinde bir yandan Zoabi'nin İsrail devletine karşı faaliyetlerini ve Zoabi'nin sistem karşıtı eylemlerini, diğer yandan da İsrail'in egemen sisteminin temsilcilerinin kendisine verdiği karşılıkları haberleştirerek İsrail'in değerler sistemiyle Zoabi'nin değerleri ve siyasi eylemleri arasındaki karşıtlığı ortaya koymuştur. Örneğin Zoabi’nin toplumsal kıyımlara göz yumması bakımından İsrail'i Nazi Almanya’sıyla, Filistinlileri de soykırım kurbanlarıyla benzeştirdiği yorumuna karşılık, İsrail egemen yapısını temsil eden bakan ve milletvekillerinin Zoabi'yi itirafçı, yalancı, tarih saptırıcısı, terör destekçisi, vatan haini, 5. kol olarak tanımlayan söylemlerine yer vermiştir. ${ }^{44}$ Jerusalem Post, benzer bir şekilde Zoabi’nin üç İsrailli genci kaçıran Filistinlileri terörist olarak nitelememesine ilişkin haberinde ${ }^{45}$ Zoabi’nin söylemini ortaya koyduktan sonra bu söylemi belirgin bir şekilde yadsıyan ve ötekileştiren başat söylemi açık bir şekilde yansıtmış ve bu iki söylem arasındaki farklılığı görünür kılmıştır. Bu bağlamda Jerusalem Post'un haberinde Zoabi'nin bu söyleminin hemen arkasında İsrail bakan ve milletvekillerinin Zoabi'yi çocuk kaçırmayı meşru gören ve Gazze'ye sınır dışı edilmesi gereken bir terörist ve vatan haini olarak tanımlayan söylemleri yer almıştır. ${ }^{46}$ Jerusalem Post, “Zoabi’nin Günahları” başyazısıyla bu farkı daha da netleştirmiştir. Bu yazıda Zoabi, İsrail'in demokratik değerlerini kullanarak bu İsrail egemen yapısının ortadan kalkmasını amaçlayan, İsrail karşıtı terörizmi destekleyen, Hamas'la sıkı ilişkileri bulunan, Mavi Marmara kışkırtmasına katılan, İsrail'i sömürgeci ırkçı bir yapı olarak tanımlayan ve gerçekleri çarpıtan bir figür olarak sunulmuş ve onun egemen yapıyla karşıgelimine vurgu yapılmıştır. ${ }^{47}$ Bununla birlikte Zoabi’ye karşı doğrudan kontrolsüz bir ötekileştirmenin İsrail'e zarar vereceğine işaret eden gazete, Zoabi’nin söylemleri ve kışkırtmaları her ne kadar kabul edilemez olsa da bunlara karşı başat söylemi zarif olmayan fevri yöntemlerle savunanlara da eleştiri getirmiştir. ${ }^{48}$ Bu bağlamda Jerusalem Post, açık ve ayrıştırıcı bir tavır yerine yasal zeminden sapmayan ve Zoabi’nin söylemindeki çelişkileri onun yüzüne vurabilecek tutarlı bir karşı söylemin daha etkili olacağını vurgulamıştır. ${ }^{49}$ Nitekim Zoabi'nin söylemlerini karartmayan Jerusalem Post, "ihtilaflı bir Arap milletvekili” olarak tanımladı̆̆ Zoabi’yle bir röportaj da yapmıştır. Ancak gazete bu röportajı Zoabi’nin sözlerini doğrudan okuyucularına aktarmak yerine onun söylemlerinin sonrasına Zoabi'nin egemen sistemle farklılıklarına işaret eden yönlendirici hatırlatmalar ekleyerek yeni bir çerçeve içinde sunmuştur. ${ }^{50}$ Zoabi’nin feminist bir politikacı olduğuna tali bir konu olarak değinilen röportajda, temelde Zoabi'yle egemen yapı arasındaki karşıtlıklar ve karşıgelimler ön plana çıkmıştır. Jerusalem Post Zoabi’nin neredeyse her yorumuna karşılık egemen yapıyı temsil eden bir görüşü ortaya koyarak bu ikiliği ve Zoabi’nin bu yapı açısından ötekiliğini daha

44 Ariel Ben Solomon, "Zoabi doubles down to Post: What is happening in Israel is even more dangerous in Germany", Jerusalem Post, 9 Kasim 2015, http://www.jpost.com/Israel-News/Politics-And-Diplomacy/Zoabi-doubles-down-toPost-What-is-happening-in-Israel-is-even-more-dangerous-than-Germany-432500 (Erişim Tarihi 31 May1s 2017).

45 “Zoabi: Kidnappers are not terrorists, they're fighting occupation”, Jerusalem Post, 17 Haziran 2014, http://www.jpost.com/ Pillar-of-Defense/Zoabi-Kidnappers-are-not-terrorists-theyre-fighting-occupation-359609 (Erişim Tarihi 31 Mayıs 2017).

46 Ibid.

47 “Zoabi’s Sins”, Jerusalem Post, 18 Haziran 2014, http://www.jpost.com/Opinion/Editorials/Zoabis-sins-359808 (Erişim Tarihi 31 Mayıs 2017).

48 “Think about it: The Reaction to MK Zoabi’s provocations”, Jerusalem Post, 3 Temmuz 2016, http://www.jpost.com/ Opinion/Think-about-it-The-reaction-to-MK-Zoabis-provocations-459410 (Erişim Tarihi 31 Mayıs 2017).

49 Ibid.

50 “Exclusive: An Interview with Controversial Arab MK Haneen Zoabi”, Jerusalem Post, 13 Aralık 2014, http://www.jpost. com/International/Politics-A-disproportionate-political-judgment-384426, (Erişim Tarihi 31 Mayıs 2017). 
belirgin kılmıştır.

Diğer gazetelerden farklı olarak etno-cinsiyetçi baskın yaklaşıma eleştiri getiren Haaretz, Zoabi’nin temsilinde onun kadınlığına da değinmiş, erkeklerin (veya erkek egemen sistemin) başatlığına boyun eğmeyen, ${ }^{51}$ evlenmemiş bir Arap kadını olan Zoabi’nin İsraillileri çılgına çevirdiğini vurgulayarak $^{52}$ Zoabi’nin siyasi mücadelesinin sistemin etnik olduğu kadar cinsiyetçi başatlığına karşı bir mücadele olduğunu göstermiştir.

Zoabi’nin İsrail demokrasisi için bir test olduğunun altınız çizen eden Haaretz, İsrail'in demokratik bir sisteme sahip olduğunu göstermesi için Zoabi'yi mevcut yapıdan dışlamaması gereğine işaret etmiştir. ${ }^{53}$ Bu bağlamda Haaretz, söylemleri her ne kadar uçta, aşırı, acıtıcı ve kırıcı olsa da Zoabi'nin temsil ettiği İsrailli Arap azınlığın kamusal ruh halinin demokratik yapının sürekliliği için İsrail'in kamusal yapısınca kapsanması lazım geldiğine dikkat çekmiştir. ${ }^{54}$ Zoabi’nin halim yapı içindeki "ötekiliğini” yadsımayan Haaretz, Zoabi’nin siyasi bir linçe uğramasının ${ }^{55}$ ve bu yapının unsurlarınca günah keçisi ilan edilmesinin $^{56}$ İsrail demokrasisi açısından fayda sağlamayacağını vurgulamıştır. Haaretz'de baskın olan Zoabi’nin görüş ve eylemleri nedeniyle sistem dışına itilmemesi gerektiği söylemi, bir yandan eşitlikçi bir yaklaşımı ifade ederken diğer yandan aslında İsrail baskın yapısının yeniden üretilmesi bağlamında Zoabi örneğinin araçsallaştırılabileceğini de göstermektedir. Bu bağlamda Haaretz'in bazı düşünce yazılarında Zoabi'nin sistem dışına itilmeden kontrollü ötekileştirilmesi üzerinden etno-cinsiyetçi olarak eleştirilen İsrail demokrasisinin meşrulaştırılmasına hizmet edeceği de dile getirilmiştir. ${ }^{57}$ Zoabi’nin İsrailli Arapların sistemden yabancılaşma sorunsalının bir ifadesi olduğunu belirten Haaretz, bu kesime daha fazla mali kaynak aktarımı yoluyla maddi ihtiyaçlarının karşılanmamasının ${ }^{58}$ buna koşut olarak da sistemle bütünleşmelerinin sağlanmamasının İsrailli Arapları daha sistem dışılaştıracakları ve güvenlik sorunu haline getirecekleri uyarısını da yapmıştır. ${ }^{59}$

\section{Nof Atamna-Ismail: İsrailli Ortak Yaşam Kültürünün Usta Filistinli/ Arap Aşçısı}

Nof Atamna-İsmail, eğitim düzeyi, bildiği diller ve İsrail'in Filistinli/Arap vatandaşları arasında temsil ettiği toplumsal statü açısından Hanin Zoabi’yle benzerlik gösterse de, İsraillilik ve İsrail devletinin söylemleriyle ilişkisi bakımından Zoabi'den farklıdır. Zoabi’nin aksine Filistinli/Arap kadınların durumunu sistemsel bir sorun olarak görmeyen Atamna-Ismail, toplum-içi barışın başat yapıya karşı feminist bir mücadeleyle değil, yemek alanında başlayacak uzlaşısal bir iletişimle

51 Shany Littman, “Haneen Zoabi: Apologize - or at Least Get Married”, Haaretz 24 Şubat 2015, http://www.haaretz. com/israel-news/elections/.premium-1.643827 (Erişim Tarihi 31 Mayıs 2017).

52 Ravit Hecht, “The Unmarried Arab Woman Who Drives Israelis Nuts”, Haaretz 23 Ekim 2014, http://www.haaretz. com/opinion/.premium-1.622166 (Erişim Tarihi 9 Ocak 2014).

53 "MK Zoabi Represents a Test to Israeli Democracy”, Haaretz, 1 Temmuz 2016, http://www.haaretz.com/israelnews/1.728236 (Erişim Tarihi 30 Mayıs 2017).

54 Ibid.

55 Ravit Hecht, "Political Lynching of an Israeli Arab Lawmaker”, Haaretz, 1 Temmuz 2016, http://www.haaretz.com/ opinion/.premium-1.728166 (Erişim Tarihi 30 Mayıs 2017).

56 Yariv Oppenheimer, “Haneen Zoabi, the Perfect Scapegoat”, Haaretz, 19 Haziran 2014, http://www.haaretz.com/ opinion/.premium-1.599653 (Erişim Tarihi 30 Mayıs 2017).

57 Moshe Arens, “Leave Haneen Zoabi Alone, She’s Proof Israel Is a True Democracy”, Haaretz, 10 Temmuz 2016, http:// www.haaretz.com/opinion/.premium-1.729956 (Erişim Tarihi 30 Mayıs 2017).

58 Meirav Arlosoroff, “Why Does Haneen Zoabi Say Such Things?”, 27 Haziran 2014, Haaretz, http://www.haaretz.com/ israel-news/business/.premium-1.601601, (Erişim Tarihi 30 Mayıs 2017).

59 Ibid. 
sağlanabileceği inancını dile getirmektedir. Başat söylemle mücadele ve onu yapıbozumuna uğratacak söylemsel meydan okuyuşlar yerine ona rıza gösterilerek sistemin içinden bir eşitlikçi dönüşümün yaşanabileceğine inanan Atamna-İsmail'le baskın söyleme başkaldıran Zoabi’nin İsrail basınındaki temsilleri de bu bağlamda farklılık göstermiştir.

Bu çerçevede Hayom, Nof Atamna-İsmail'i İsrail'in kültürel çeşnisinin, çok kültürlü ilişkiler ağının, toplumiçi gruplararası bağların ve İsrail' in ana değerlerini özümlemenin başarılı bir örneği olarak sunmuştur. ${ }^{60}$ İsraillilerin bir İsrail üniversitesinden mikrobiyoloji doktoralı Müslüman bir Arap kadını olan Atamna-İsmail'i televizyonların en çok izlendiği zaman diliminde evlerinde konuk etmekten ve onun rehberliğinde onun önerdiği yemekleri yapmaktan rahatsızlık duymadıklarını belirten Hayom, İsraillilik değerlerine uygun hareket eden Filistinli/Arap kadınların toplumun çoğunluğu tarafından kanıksanacağı mesajını vurgulamıştır. ${ }^{61}$ İsraillilerin Atamna-İsmail gibi İsrail'in kendilerine sunduğu eşit haklardan yararlanan bir azınlık mensubunun günlük yaşamlarının bir parçası haline gelmesinden mutlu olduklarını vurgulayan Hayom, İsrail vatandaşı Filistinliler/Araplar kadar Filistin Yönetimi bölgesinden de Atamna-İsmail gibi örneklerin çıkmasının ayrım duvarlarının ve toplumsal sınırların ortadan kalmasına yardımcı olabileceğini anıştırmıştır. ${ }^{62}$ Sayfalarında Atamna-İsmail'le yapılan röportaja geniş yer ayıran Hayom, Atamna-İsmail'in İsrail'de yaşayan her Yahudi vatandaşın yapabileceği İsrail’le ilgili sistem-içi eleştirilere yer vermiş, ancak temel söyleminde İsrailli-Arap vatandaşların eğer çaba gösterirlerse Atamna-İsmail gibi bu zorlukları aşabileceklerini vurgulamıştır. ${ }^{63}$ Atamna-İsmail'in İsrailli-Araplar arasındaki cinsiyetçi hiyerarşinin varlığına dair anıştırmalarını da sayfalarına taşıyan Hayom, İsrailli-Araplar arasında geleneksel olarak kadının gördüğü baskının üretim/yeniden üretim alanlarından biri olarak kabul edilen mutfağın Master-Chef te olduğu gibi birleştirici, özgürleştirici ve yetkinleştirici bir alana dönüştürülebileceğini de Atamna-İsmail'in yorumuyla okuyucuya sunmuştur. ${ }^{64}$ Atamna-İsmail'in kendi kocasını tasvirine atıfla İsrailli-Arap toplumu arasında özgür ve kendisine yeten kadınları taşıyabilecek az sayıda erkek olduğu mesajını da ileten Hayom, İsrailli-Arap toplumunun kendi içindeki cinsiyetçi hiyerarşisine de değinmiştir. Başat söyleme koşut bir şekilde, Atamna-İsmail'in yorumuyla İsrailli-Arapların İsraillilik ortak değerleri düzleminde ortak bir yaşam arzusu duydukları ve ülkenin kendilerine sunduğu imkânlardan mutlu oldukları mesajını okuyucularına aktaran Hayom, ${ }^{65}$ yemek aracılığıyla toplumsal uzlaşıyı amaçlayan ve bu yönde yaşayarak başarılı olan bir İsrailli-Arap kadını temsiliyetini ön plana çıkarmıştır.

Hanin Zoabi'yi İsraillilik değerlerine bir tehdit olarak gören ve ötekileştirme pratiği içinde kadınlığına da "İsrailli olmayan kadınların" durumlarına bağdaşık bir atıfla vurguda bulunan Maariv gazetesi, Atamna-İsmail'in başarısını da tam bir uyum ve bütünleşme hikâyesi olarak okurlarına yansıtmamıştır. İbranice sürümünde bulunan haberlerin yalnızca birinde Atamna-İsmail'in başarısının toplumsal bir normalleşmeye işaret edebileceği mesajı verilirken ${ }^{66}$, Master-Chef yarışması sayesinde İsrailli izleyiciye İsrail içinde yaşayan Araplardan korkmak yerine onları tanımak için bir

60 Emily Amrousi, "Equality before law”, 11 Nisan 2014, Israel-Hayom, http://www.israelhayom.com/site/ newsletter_ opinion.php?id=8047, (Erişim Tarihi 31 Mayıs 2017).

61 Ibid.

62 Ibid.

63 Hila Alpert, “Çocuksu Nof” [Yaldutiy Nof] , 4 Nisan 2014, Israel-Hayom http://www.israelhayom.co.il/article / 171817 (Erişim Tarihi 31 Mayıs 2017).

64 Ibid.

65 Ibid.

66 “Mira Avad: Bütün Tuhaflı̆̆ına Rağmen, İsrailliler Araplardan Korkmaya Devam Ediyor” [Mira Avad: Im Kol Gihukh, Haİsraelim Adayin Mufhadim MiAravim], Maariv, 13 Nisan 2014, http://www.maariv.co.il /news/new. aspx?pn6Vq=L\&0r9VQ=FFIHJ (Erişim Tarihi 30 Mayıs 2017). 
fırsat yaratıldığına vurgu yapılmıştır. ${ }^{67}$ Diğer haberlerde Master-Chef yarışmasının İsrail toplumu içindeki kültürel çeşniyi ekranlara getirdiği ifade edilirken, Nof Atamna İsrailli izleyiciler tarafından en çok izlenen program olan Master-Chef programında ${ }^{68}$ Etiyopyalı bir Yahudi ve bu İsrail sosyokültürel çeşnisinin bir öğesi olarak sunulmuştur. ${ }^{69}$ Atamna-İsmail'in yarışmanın başından sonuna dek geleneksel Arap mutfağına modern dokunuşlar yaparak finale kadar geldiğini vurgulayan Maariv, Atamna-İsmail’in geleneksel (üç çocuk annesi ve mutfakta başarılı) ile modern (doktora sahibi bilim insanı, mikrobiyolog) özelliklerine değinmiş ve yarışma sonrasında Yahudi-Arap aşçılık okulu açma hayalini artık gerçekleştirebileceğini vurgulamıştır. ${ }^{70}$

Yediot-Aharanot, haber ve yorumlarında Nof Atamna-İsmail'i köklerini inkar etmeyen, yapmacık olmayan, ödün vermeyen ve kendine özgü bir mikrobiyolog olarak tanımlamış, aile yapısında mevcut İsrail yaşam kültürüyle özdeşik özelliklerine (eğitimli, ailesine önem veren üç çocuk annesi); egemen İsrailli yapıyla etkileşimine (çocukluğunda Yahudi okulunda okuması, annesinin İbranice öğretmeni olması) ve İsraillilik bağlamında ortak gelecek ülküsüne (yarışma sonrası bir Yahudi-Arap yemek okulu açma hayali) vurgu yapmıştır. ${ }^{71}$ Haber ve yorumlarını İsrail'de birlikte yaşama ve yemek programında Atamna-İsmail'in başarısının ortak yaşam kültürünün geliştirilmesindeki araçsallığı çerçevesinde okurlarıyla paylaşan Yediot-Aharonot'un temel mesajı, İsrail'deki ortak yaşam kültürünün Nof ve İsrail toplumunun farklı kesimlerden Master-Chefe katılan yarışmacıların yarışma kurgusunun ve ekranların dışında da aynı tabaktan yemek yemeye başladıklarında gelişebileceği olmuştur. ${ }^{72}$ İsrail toplumu içindeki Araplarla Yahudiler arasındaki barışın ve duygudaşlığın ortak büyük güzel bir tabaktan birlikte yemek yemeyle başlayabileceği benzeşimini yapan Yediot-Aharonot, Nof'un Master-Chef teki başarısının bu umut için bir örnek olduğunu vurgulamıştır.

Hanin Zoabi'yi temsilinde Zoabi'nin söylemleri ve başat söylem arasındaki bariz farklılıklara işaret eden Jerusalem Post, Atamna-İsmail'in temsilinde benzerlikleri ve ortak yaşam vurgusunu belirgin kılan bir söylemi öne çıkarmıştır. Diğer gazeteler gibi Atamna-İsmail’in biliminsanlı̆̆ı, anneliği, İsrailli bir Arap oluşu gibi özelliklerini belirten Jerusalem Post, ayrıca bu farklı niteliklerin birbirleriyle uyum içinde kullanıldığında başarıyı getirdiğini vurgulayarak, Atamna-İsmail'in bilimsel netlik ve hassasiyetini Arap mutfağını sergilemekteki tutkusuyla birleştirmesini övmüştür. ${ }^{73}$ Atamnaİsmail'in ortak Yahudi-Arap yemek okulu ve İsrail toplumunun hem Yahudi hem de Arap kesimlerini hedefleyen bir aşçllık okulu açma amacına vurgu yapan Jerusalem Post, yarışma sırasında Atamnaİsmail'in toplumsal ortak yaşamı mümkün kılan arkadaş canlısı iletişim özelliklerini överken, bu özellikleri doğru kullandığında yarışma sırasında kendisi için dua edecek bir haham arkadaş bile

67 Ibid

68 “Master Şef Finalinin Rekor İzlenme Oranı: \%42.7” [Siy Reyting LeMaster Şef Beg'mar: \%42.7], Maariv, 6 Nisan 2014, http://www.maariv.co.il/news/new.aspx?pn6Vq=L\&0r9VQ=FFEIM (Erişim Tarihi 30 Mayıs 2017).

69 "Master Şef Finalinden Hemen Önce Finalistlerle Buluştuk” [Rega Lifney Gmar Hagadol: Pagaşnu et Hafinalistim şel Master Şef], Maariv, 5 Nisan 2014, http://www.maariv.co.il/news/new.aspx?pn6Vq= L\&0r9VQ=FFEDD , (Erişim Tarihi 30 Mayıs 2017).

70 “Master-Şef 4.Sezonunun Şampiyonu: Nof” [Hazakhah Hagdola şel Master Şef 4: Nof], Maariv, 6 Nisan 2014, http:// www.maariv.co.il/news/new.aspx?pn6Vq=L\&0r9VQ=FFEHK, (Erişim Tarihi 30 Mayıs 2017).

71 Ariana Melamed, “Master-Şef: Barış bir tabakla (yemek) başlar” [Gmar Master Şef: Haşalom Mathil Betzalahat], 6 Nisan 2014, http://www.ynet.co.il/articles/0,7340,L-4507101,00.html; Raz Shechnik, "Arab microbiologist is Israel's new 'Master-Chef', 6 Nisan 2014, http://www.ynetnews.com/articles/0,7340,L-4507263,00.html (Erişim Tarihi 9 Ocak 2015); "Nof Atamna-İsmail Master-Şef finalini kazandı" [Nof Atamna Ismael zahat Begmar Master Şef], Yediot-Aharanot, 5 Nisan 2014, http://www.ynet.co.il/articles/0,7340,L-4507035,00.html (Erişim Tarihi 31 Mayıs 2017).

72 Ibid.

73 “Arab-Israeli microbiologist wins Israel's Master Chef”, Jerusalem Post, 7 Nisan 2014, http://www.jpost.com/ Arts-andCulture/Arts/Arab-Israeli-microbiologist-wins-Israels-Master-Chef-347815 (Erişim Tarihi 31 Mayıs 2017). 
bulabildiği mesajını vermektedir. ${ }^{74}$ Bir başka yazısında Atamna-İsmail’i Yahudi ve Arap usta aşçıların geleneksel Arap mutfağına modern dokunuşlarla yeni tatları kattığı bir yemek festivalinin kurucusu ve yaratıcı yönetmeni olarak sunan Jerusalem Post, Atamna-İsmail'in başat söylemde de özellikle vurgulanan ortak yaşam vurgusunu ön plana çıkarmıştır. ${ }^{75}$ Atamna-İsmail'in problemli zamanlarda bile yemeğin insanları bir araya getirebileceği ve Yahudi-Arap ortak yaşamının siyaset yerine işbirliği, dayanışma ve takım çalışmasının hakim olduğu mutfaktan başlayarak pekiştirilebileceği söylemlerini başat sistemi temsil eden Hayfa Belediye Başkanı'nın yemek festivalinin yalnızca yemeklerle ilgili olmadığı aynı zamanda birlikte yaşama kültürünü ifade ettiğine vurgu yapan söylemiyle bir arada okuyucularına sunmuştur. ${ }^{76}$ Jerusalem Post bu anlamda Atamna-İsmail'in söylemiyle başat söylem arasındaki özdeşliği belirgin kılmıştır.

Diğer gazeteler gibi Atamna-İsmail’in Master-Chef yolculuğunu İsrailli Arapların çok kültürlü İsrail egemen yapısı içindeki bir başarı öyküsü olarak sunan Haaretz, İsrail'in Arap şehri Baka-alGarbiye'den üç çocuklu, mikrobiyoloji doktoralı Atamna-İsmail'in yarışmadan kazandığı parayı Yahudi ve Arapların birlikte eğitim alacağı bir aşçlık okulu açmakta kullanacağını belirtmiştir. ${ }^{77}$ Dine ve tabiiyete bakmaksızın hayata, yemek pişirmeye ve Filistin yerel mirasına tutkulu Atamna-İsmail'i ${ }^{78}$ geleneksel tatlarla modern teknikleri harmanlayan ve toplumu yemek aracıllğıyla bütünleştiren birleştirici bir figür olarak resmeden Haaretz, onun eylem ve söylemlerini yarışma bağlamı dışında da okuyucularıyla buluşturmuştur. Bu bağlamda örneğin, İsrailli Arapların hakim yapıyla sosyoekonomik ilişkileri çerçevesinde onun Yahudi şeflerle birlikte hayata geçirdiği "Yerel Arap Mutfağı Ayı” projesini küçük ölçekli İsrailli Arap üreticilerin İsrail gıda pazarında hayatta kalma mücadelelerine destek verilerek toplumsal bütünleşmelerine katkı koyulmasının bir örneği olarak sunmuştur. ${ }^{79}$ İsrailli Arapların ve Yahudilerin yemeği bir barış dili olarak kullanmaları arayışında ${ }^{80}$ Atamna-İsmail'in sözlerine atıfta bulunan Haaretz, yemeğin tek başına barışı getirmese de onun aracılığıyla irkçılığın bir kenara bırakılarak birlikte yaşamak isteyen insanların birbirlerini daha iyi tanımaları için ortak bir zemin yaratılabileceğine dair umudu dile getirmiştir. ${ }^{81}$

\section{Sonuç}

Tarihsel olarak ataerkil bir Yahudi egemen devlet söyleminin ideolojik bir aygıtı şeklinde hizmet veren İsrail anakım medyası, zaman içinde güvenlik odaklı ayrımcılıktan rıza oluşturmaya dayalı hegemonyaya doğru söylemsel bir dönüşümden geçmiştir. Bu dönüşümün mevcut durumuna bakıldığında İsrail anaakım basınının İsrail' in Filistinli/Arap vatandaşlarının temsilinde etno-cinsiyetçi basmakalıp önyargıların hâkim olduğu ayrımcı bir ötekileştirme söylemi yerine daha kontrollü bir ötekileştirme söylemini takip ettiğini gözlemlemek mümkündür. Toplumsal dönüşümlere ve başat

74 Ibid.

75 "A tasty look at coexistence in Haifa", Jerusalem Post, 5 Aralık 2016, http://www.jpost.com/Israel-News /Culture/Atasty-look-at-coexistence-in-Haifa-474512 (Erişim Tarihi 31 Mayıs 2017).

76 Ibid.

77 Ruta Kupfer, “Israeli Arab Wins Reality Cooking Show 'Master Chef”, Haaretz, 6 Nisan 2014, http://www.haaretz. com/life/2.1248/1.583998i, (Erişim Tarihi 30 Mayıs 2017).

78 Ronit Vered, “The Best Arab Food You Never Tasted”, Haaretz, 3 Haziran 2015, http://www.haaretz.com/jewish/ food/1.664104, (Erişim tarihi 30 Mayıs 2017).

79 Ibid.

80 "New Festival Seeks to Keep Historical Arab Foods From Disappearing”, Haaretz, 10 Aralık 2015, http://www.haaretz. com/jewish/food/1.691067, (Erişim Tarihi 30 Mayıs 2017).

81 Ibid. 
ideolojinin zaman içinde değişen iletişimsel önceliklerine ve mesaj seçimlerine koşut olarak gelişen bu kontrollü ötekileştirme "sistem-içilik" ve "sistem karşıtı olmak" bağlantı skalasında gerçekleşmektedir. Bu kontrollü ötekileştirme, bir yandan etnik kökenden bağımsız olarak mevcut yapıda var olan cinsiyet temelli eşitsizlikleri ikincilleştirirken aynı zamanda İsrail vatandaşı Filistinli/Arap kadınların içinde yer alabileceği cinsiyet temelli bütünlükçü bir iletişimsel alternatifin ve ataerkil egemen sistem karşıtı yapıbozumcu bir söylemin oluşmasını engellemektedir.

Bütünlükçü bir feminist direniş stratejisinin ve ataerkil egemen sistem karşıtı yapıbozumcu bir güçler birliğinin yokluğunda Filistinli/Arap kadının gerek toplumsal eşitliğinin sağlanması gerekse medyadaki temsilinin daha eşitlikçi bir anlayışla gerçekleşmesi çok zordur. Filistin kadını azınlığın, azınlığı olduğu etnik-dinsel bir ataerkil sistemin içinde hak kazanım mücadeleleri vermektedir. Ancak, sistemin yapısal dokusu değişmedikçe, bu mücadeleler mevcut sistemin yapısal anlamda bir bozuma uğratılmasından çok onun yeniden üretilmesine yardım edebilir. Nitekim İsrail vatandaşı Filistinli/ Arap kadınların kazandığı haklar da ancak İsrail değerler sistemiyle oluşturulmuş bir yapıda anlam kazanacakları için, doğası itibariyle birbirine ters gibi görünse de birbirini tamamlayan bir şekilde o yapıyı besleyebileceklerdir.

$\mathrm{Bu}$ anlamda Filistin kadınının İsrail toplumunda kendisini ifade etme bağlamında özgürleştirici adımlar atabilmesi için başat medya söylemine alternatif söylem ve temsil üretebilen eşitlikçi bir medya söylemini yaratabilecek iletişim düzeneklerini oluşturması gerekmektedir. İsrail vatandaşı Filistinli/Arap kadınların, kendi içlerindeki bölünmüşlüğün değişik düzlemlerde sürdügü (dinci-laik, geleneksel-modern, zengin-fakir, eğitimli-eğitimsiz vs.) ve alternatif medya araçlarını/alanlarını etkin bir şekilde geliştirme ve kullanmak için gerekli ekonomik altyapının yeterli olmadığı bir ortamda bu mekanizmaları oluşturmaları kolay görünmemektedir. Nof Atamna-İsmail ve Hanin Zoabi gibi bu düzlemler bazında bölünmemiş ve birbirine benzer niteliklere sahip İsrail vatandaşı Filistinli/ Arap kadınları bile birbirinden ayrıştıran ve cinsiyet temelli ortak bir karşı duruşu üretmelerine engel olan temel bölünmüşlükse, onların İsrail başat yapısı/değerleriyle ilişkilerindeki seçimlerinde ve konumlanışlarında ortaya çıkan "sistem-içilik" - "sistem-karşıtı olma” bölünmüşlüğüdür. İsrail vatandaşı Filistinli/Arap kadınlar arasındaki bölünmüşlükleri de pekiştiren bu temel bölünmüşlük düzlemi, İsrail başat yapıları tarafından banal bir şekilde yeniden üretilmekte ve İsrail'in anaakım basını da bu ikiliğin yeniden üretilmesinde başat ideolojinin söylemine karşıt bir söylem üretmemekte, doğrudan veya dolaylı olarak bu söylemin yeniden üretilmesine hizmet vermektedir. 